\title{
EFEKTIVITAS SUPLEMENTASI ZAT BESI DAN VITAMIN C UNTUK MEMPERBAIKI STATUS ANEMIA SANTRI
}

\section{Efficacy of Iron and Vitamin C Supplementation for Improving Anemia Status among Boarding School Students}

\author{
Kartika Pibriyanti ${ }^{1 *}$, Susi Nurohmi ${ }^{1}$, Dianti Desita Sari ${ }^{1}$ \\ ${ }^{1}$ Program Studi Gizi, Fakultas IImu Kesehatan, Universitas Darussalam Gontor \\ Jalan Raya Siman KM 6, Ponorogo, Jawa Timur, Indonesia \\ *e-mail: dkartika.02@gmail.com
}

Submitted: September $24^{\text {th }}, 2020$, revised: November $18^{\text {th }}, 2020$, approved: June $2^{\text {nd }}, 2021$

\begin{abstract}
Background. Anemia has become a widespread nutritional issue in Indonesia and even around the world. This issue needs to be overcome because it has an impact on the quality and productivity of human resources. One of the efforts to reduce the prevalence of anemia is to provide iron supplementation for adolescents. Some researches showed vitamin could increase iron efectivity. Objective. This study aimed to analyze the efficacy of iron and vitamin $C$ supplementation on anemia in boarding school students. Method. Subjects participating were 56 female adolescent students aged 16 to 18 years old with hemoglobin levels of $<12 \mathrm{~g} / \mathrm{dL}$. The research design was quasi-experimental with two treatment groups. One group received iron (Fe), while the other received iron and vitamin $\mathrm{C}(\mathrm{Fe}+\mathrm{Vit} \mathrm{C})$. The treatment consisted of weekly supplementation for 90 days. Statistical analysis was used to identify the differences between two treatment groups (Independent sample t-test and Mann Whitney) as well as treatment changes (Paired sample t-test and Wilcoxon). Result. The results showed that more than half of the subjects had normal nutritional status as seen from BMI for Age, mid-upper arm circumference (MUAC), and waist circumference. Prior to the intervention, the majority of subjects in the Fe group (58.6\%) had mild anemia while 55.6 percent in the $\mathrm{Fe}+\mathrm{Vit} \mathrm{C}$ group had moderate anemia. Before intervention, hemoglobin levels in the Fe and Fe+Vit C groups were $10.7 \mathrm{~g} / \mathrm{dL}$ and $11.1 \mathrm{~g} / \mathrm{dL}$, respectively. After the intervention, hemoglobin levels in $\mathrm{Fe}$ and $\mathrm{Fe}+\mathrm{Vit} \mathrm{C}$ groups increased significantly to $13.0 \mathrm{~g} / \mathrm{dL}$ and $12.4 \mathrm{~g} / \mathrm{dL}$, respectively. However, there was no significant difference in hemoglobin levels between the two treatment groups after intervention. Conclusion. Iron supplementation with or without vitamin C improved the anemia status among subjects even though hemoglobin levels in the two groups were not significantly different after the intervention.
\end{abstract}

Keywords: adolescent, anemia, iron supplementation, vitamin C

\begin{abstract}
ABSTRAK
Latar Belakang. Anemia masih merupakan permasalahan gizi yang dihadapi oleh Indonesia bahkan dunia. Salah satu upaya untuk mengurangi prevalensi anemia adalah memberikan suplementasi zat besi pada remaja. Beberapa penelitian membuktikan efektivitas zat besi meningkat dengan adanya vitamin. Tujuan. Penelitian ini bertujuan untuk menganalisis pengaruh pemberian suplemen zat besi dan vitamin $C$ pada santri. Metode. Subjek yang berpartisipasi dalam penelitian ini adalah santri berusia 16-18 tahun berjumlah 56 orang yang mengalami anemia dengan kadar hemoglobin $(\mathrm{Hb})<12 \mathrm{~g} / \mathrm{dL}$. Desain penelitian yang digunakan adalah kuasi eksperimental dengan dua kelompok perlakuan yaitu kelompok suplementasi zat besi (Fe) dan kelompok suplementasi zat besi dan vitamin C ( Fe+Vit C). Perlakuan dilakukan selama 90 hari dengan satu minggu sekali pemberian suplemen. Analisis statistik digunakan untuk
\end{abstract}


melihat perbedaan variabel dari dua kelompok perlakuan (Independent sample t-test dan Mann Whitney) serta perubahan yang terjadi sebelum dan sesudah perlakuan (Paired sample t-test dan Wilcoxon). Hasil. Hasil penelitian menunjukkan bahwa lebih dari mayoritas subjek memiliki status gizi yang normal dilihat dari parameter IMT/U, lingkar lengan atas (LiLA), dan lingkar pinggang. Sebelum intervensi dilakukan, sebagian besar subjek pada kelompok $\mathrm{Fe}(58,6 \%)$ memiliki status anemia ringan sementara pada kelompok Fe+Vit C, 55,6 persen dikategorikan memiliki status anemia sedang. Rata-rata kadar $\mathrm{Hb}$ sebelum intervensi pada kelompok $\mathrm{Fe}$ adalah $10,7 \mathrm{~g} / \mathrm{dL}$ sedangkan pada kelompok $\mathrm{Fe}+\mathrm{Vit} \mathrm{C}$ adalah $11,1 \mathrm{~g} / \mathrm{dL}$. Kadar $\mathrm{Hb}$ mengalami peningkatan secara signifikan pada kelompok Fe dan Fe+Vit $C$ menjadi $13,0 \mathrm{~g} / \mathrm{dL}$ dan $12,4 \mathrm{~g} / \mathrm{dL}$ setelah intervensi dilakukan. Namun demikian tidak terdapat perbedaan yang signifikan pada kadar $\mathrm{Hb}$ setelah intervensi antara kedua kelompok perlakuan. Kesimpulan. Suplementasi Fe maupun Fe+Vit C dapat memperbaiki status anemia pada santri meskipun kadar $\mathrm{Hb}$ pada kedua kelompok tidak berbeda nyata setelah intervensi.

Kata kunci: remaja, anemia, suplementasi besi, vitamin C

\section{PENDAHULUAN}

Anemia merupakan masalah kesehatan dunia yang dialami oleh negara dengan tingkat ekonomi menengah ke bawah maupun menengah ke atas. ${ }^{1}$ Badan kesehatan dunia (WHO) menyatakan bahwa secara global, sebanyak 800 juta anak dan wanita pada tahun 2011 mengalami masalah anemia. Persentase tertinggi berada pada anak usia pra sekolah (6-59 bulan) sebesar 42,6 persen dan pada ibu hamil (15-49 tahun) sebesar 38,2 persen. ${ }^{2}$ Adapun prevalensi anemia di Indonesia pada usia 15-24 tahun adalah 32 persen, sementara pada ibu hamil di usia yang sama sebesar 84,6 persen. ${ }^{3}$ Prevalensi anemia pada remaja putri adalah 18,8 persen sementara pada remaja putra adalah 11 persen. ${ }^{4} \mathrm{Hal}$ ini merupakan masalah serius yang perlu perhatian dan partisipasi berbagai pihak.

Upaya yang dilakukan pemerintah Indonesia salah satunya adalah pemberian tablet tambah darah (TTD) yang berisi zat besi elemental 60 mg kepada remaja dan ibu hamil. Cakupan pemberian TTD pada remaja putri di sekolah mencapai 80,9 persen. Namun demikian, hanya
1,4 persen saja yang mendapatkan $\geq 52$ tablet. $\mathrm{Hal}$ ini berarti hampir keseluruhan remaja putri yang tercatat pada cakupan hanya mendapatkan TTD $<52$ tablet. $^{3}$ Salah satu evaluasi dari permasalahan ini adalah ketersediaan tablet tambah darah bagi remaja putri belum terfasilitasi oleh pusat (Ditjen Farmasi dan Alat Kesehatan). Oleh karena itu, pada pelaksanaan pemberian tablet tambah darah bagi remaja putri sangat tergantung pada kelebihan persediaan dari tablet tambah darah bagi ibu yang ada di daerah. ${ }^{5}$

Program pemberian TTD pemerintah perlu dioptimalkan karena menurut Permatasari et al. prevalensi anemia dengan indikator kadar hemoglobin $<12 \mathrm{~g} / \mathrm{dL}$ di Kota Bogor dapat diturunkan dari 20,7 persen menjadi 15,2 persen. ${ }^{6}$ Kadar hemoglobin $(\mathrm{Hb})$ merupakan parameter yang sering digunakan untuk melihat status anemia. Anemia merupakan kondisi dimana tubuh kekurangan sel darah merah sebagai pembawa oksigen. Ketercukupan akan sel darah merah bervariasi berdasarkan usia, jenis kelamin, demografi, kebiasaan merokok, dan kondisi fisiologis seperti kehamilan. Defisiensi zat besi merupakan faktor yang paling sering ditemukan sebagai penyebab anemia secara 
global meskipun disamping zat besi, terdapat beberapa zat gizi lain yang juga dapat memicu terjadinya anemia termasuk asam folat, vitamin B12, dan vitamin A. Penilaian kadar hemoglobin merupakan parameter yang digunakan untuk mendapatkan informasi mengenai tingkat keparahan defisiensi zat besi. ${ }^{7}$

Zat besi adalah zat gizi penting untuk kehidupan karena peran utamanya dalam berbagai proses seluler. ${ }^{8}$ Logam transisi ini juga merupakan komponen penting dari dalam sel darah merah, di mana 200 miliar sel darah merah baru diproduksi setiap hari. ${ }^{9}$ Metabolisme zat besi di dalam tubuh salah satunya dipengaruhi oleh keberadaan zat gizi lain seperti protein dan vitamin. Vitamin yang dapat membantu penyerapan zat besi adalah vitamin $\mathrm{C}$ atau asam askorbat. ${ }^{10}$ Asam askorbat yang diketahui sebagai zat gizi penting dalam pembentukan kolagen dan pencegahan scurvy berfungsi juga sebagai kofaktor dalam berbagai reaksi metabolisme dalam tubuh. Namun demikian tubuh tidak dapat melakukan sintesis asam askorbat sehingga vitamin $\mathrm{C}$ merupakan zat gizi esensial yang perlu didapatkan dari diet. ${ }^{8}$

Menurut Krisnanda pemberian vitamin C bersamaan dengan suplementasi zat besi memberikan pengaruh terhadap status zat besi dengan meningkatkan absorpsinya. ${ }^{10}$ Hasil penelitian yang dilakukan pada hewan coba menyebutkan bahwa keberadaan asam askorbat di dalam diet dapat meningkatkan absorpsi zat besi nonheme dalam usus dan membantu regulasi uptake zat besi ke dalam sel. Asam askorbat memodulasi metabolisme zat besi dengan menstimulasi sintesis ferritin, menghambat degradasi ferritin lisosom, dan menurunkan tingkat penghabisan zat besi dalam sel. Selain itu, asam askorbat juga memiliki kemampuan dalam meningkatkan kinerja transferin dalam metabolisme zat besi di dalam tubuh. ${ }^{8}$ Oleh sebab itu, penelitian ini bertujuan untuk mengetahui pengaruh suplementasi zat besi dan vitamin $C$ terhadap perbaikan status anemia pada santri.

\section{METODE}

Penelitian ini merupakan studi kuasi eksperimental dengan paired samples clinical trials design dan bagian dari penelitian besar yang berjudul "Model Perbaikan Status Gizi Remaja dalam Upaya Menurunkan Angka Anemia pada Santri". ${ }^{11}$ Penelitian tersebut telah mendapatkan persetujuan dari Komisi Etik Penelitian Kesehatan Fakultas Kedokteran Universitas Muhammadiyah Surakarta dengan nomor 2930/B.2/KEPK-FKUMS/III/2020. Subjek yang berpartisipasi dalam penelitian adalah remaja putri yang merupakan santriwati Pondok Modern Darussalam Gontor Putri 1 usia 16-18 tahun dengan status anemia yang dibuktikan dengan kadar $\mathrm{Hb}<12 \mathrm{~g} / \mathrm{dL}$. Penelitian dilakukan pada bulan Maret-Juli 2020. Dari hasil perhitungan rumus $n=\frac{\left(z_{\alpha}+z_{\beta}\right)^{2} x 2 \sigma^{2}}{d^{2}}$ dengan $z_{\alpha} 5$ persen $(1,96)$, kekuatan tes 90 persen, simpangan baku kadar hemoglobin dan selisih rerata kadar hemoglobin yang dianggap berarti $0,69 \mathrm{~g} / \mathrm{dL}$ dan $1,2 \mathrm{~g} / \mathrm{dL} .{ }^{12}$ Estimasi drop out 10 persen didapatkan jumlah sampel minimum 23 orang untuk setiap kelompok. Pada proses skrining didapatkan jumlah subjek anemia 62 orang.

Keseluruhan subjek dibagi menjadi dua kelompok secara acak masing-masing 31 orang. Kelompok pertama mendapatkan perlakuan berupa suplementasi $\mathrm{Fe}$ dan kelompok kedua 
mendapatkan suplementasi Fe dan vitamin C. Suplementasi yang diberikan mengacu pada ketentuan WHO. ${ }^{13}$ Jumlah Fe elemental 60 mg dari ketentuan 30-60 mg/hari. Sementara itu dosis vitamin $\mathrm{C}$ yang digunakan adalah 50 $\mathrm{mg} /$ hari. Vitamin $\mathrm{C}$ yang digunakan adalah vitamin C IPI diperoleh dari apotek. Pemberian suplementasi dilakukan secara single blind selama 90 hari dan diberikan setiap satu minggu sekali pada subjek.

Variabel yang diukur dalam penelitian ini meliputi status gizi, tekanan darah, dan kadar hemoglobin. Penilaian status gizi dilakukan melalui pengukuran antropometri yang terdiri atas IMT/U, lingkar lengan atas (LiLA), dan lingkar pinggang. Kategori status gizi berdasarkan IMT/U mengacu pada nilai z-score yang ditetapkan oleh Kemenkes RI. ${ }^{14}$ Kategori status gizi berdasarkan z-score terdiri atas gizi kurang (-3 SD s/d $\leq-2 \mathrm{SD})$, normal (-2 SD s/d $\leq 1 \mathrm{SD}$ ), gizi lebih (1 SD s/d $\leq 2 \mathrm{SD}$ ), dan obesitas (>2 SD). ${ }^{15}$ Kategori LiLA dibagi menjadi dua, yakni $<23,5 \mathrm{~cm}$ (berisiko Kurang Energi Kronis/KEK) dan $\geq 23,5 \mathrm{~cm} .{ }^{14}$ Klasifikasi lingkar pinggang terdiri atas $<80 \mathrm{~cm}$ dan $\geq 80 \mathrm{~cm} .{ }^{16}$ Variabel tekanan darah baik sistolik maupun diastolik diklasifikasikan menjadi hipotensi (<90/60 mm/Hg), normal (90/60-119/79 mm/ $\mathrm{Hg}$ ), prehipertensi (120/80-139/89 mm/Hg), dan hipertensi $(\geq 140 / 90 \mathrm{~mm} / \mathrm{Hg}) .{ }^{17}$ Kadar $\mathrm{Hb}$ sebagai indikator anemia dikategorikan menjadi nonanemia ( $\geq 12 \mathrm{~g} / \mathrm{dL}$ ), anemia ringan (11-11,9 $\mathrm{mg} / \mathrm{dL})$, anemia sedang $(8-10,9 \mathrm{mg} / \mathrm{dL})$, dan anemia berat $(<8 \mathrm{~g} / \mathrm{dL}){ }^{7,6}$

Alat ukur $\mathrm{Hb}$ yang digunakan adalah Easy Touch GCHb tipe ET-321 buatan Taiwan, blood lancet, test chip, pen lancing device, alcohol swab, dan strip hemoglobin. Prosedur penggunaannya, ujung jari yang akan ditembak jarum dibersihkan dengan alcohol swab, jarum ditembakkan dan ditekan supaya darah keluar. Darah disentuhkan pada tepi samping strip kemudian setelah darah meresap sampai ujung strip dan ada bunyi beep, hasil sudah bisa dilihat beberapa detik pada layar. Data asupan energi dan zat gizi dinilai dengan menggunakan semi quantitative food frequency questionnaire ( $S Q$ FFQ) yang dilakukan di akhir intervensi untuk melihat gambaran asupan energi dan zat gizi selama tiga bulan terakhir selama masa intervensi dilakukan. Adapun zat gizi yang dinilai adalah protein, vitamin $A$, vitamin $C$, vitamin $B 12$, asam folat, kalsium, zat besi, dan zink. Tingkat kecukupan energi dan zat gizi dihitung dengan membandingkan data asupan dengan angka kecukupan zat gizi 2019. ${ }^{18}$

Analisis statistik dilakukan secara univariat dan bivariat. Analisis bivariat digunakan untuk melihat perbedaan rerata dua kelompok intervensi atau melihat perbedaan rerata sebelum dan sesudah intervensi. Perbedaan rata-rata variabel antara kelompok $\mathrm{Fe}$ dan $\mathrm{Fe}+\mathrm{Vit}$ $\mathrm{C}$ dianalisis menggunakan independent sample t-test untuk data yang memiliki sebaran normal. Pengujian kadar hemoglobin, asupan energi, protein, vitamin $\mathrm{A}$, vitamin $\mathrm{C}$, zat besi, dan zink pada kedua kelompok menggunakan uji Mann Whitney dikarenakan distribusi data yang tidak normal. Sementara itu, pada pengujian ratarata variabel sebelum dan sesudah perlakuan dilakukan dengan paired sample t-test kecuali pada variabel kadar hemoglobin kelompok $\mathrm{Fe}+\mathrm{Vit} \mathrm{C}$ sebelum dan sesudah intervensi menggunakan uji Wilcoxon dikarenakan data tidak terdistribusi normal. 
HASIL

Jumlah seluruh subjek pada awal penelitian dilakukan adalah 62 orang yang terbagi dalam dua kelompok. Selama penelitian berlangsung terdapat dua orang di kelompok Fe dan empat orang di kelompok Fe+Vit C drop out sehingga di akhir penelitian terdapat 56 orang. Dari hasil penelitian yang disajikan dalam Tabel 1 menunjukkan bahwa nilai IMT berada pada kisaran normal untuk remaja yaitu $21,8 \pm 3,3$ $\mathrm{kg} / \mathrm{m}^{2}$ pada kelompok Fe dan $21,9 \pm 2,7 \mathrm{~kg} / \mathrm{m}^{2}$ pada kelompok Fe+Vit C. Rata-rata LiLA pada kelompok Fe dan Fe+Vit C tergolong normal $(\geq 23,5 \mathrm{~cm})$. Demikian juga lingkar pinggang menunjukkan bahwa rata-rata kedua kelompok memiliki lingkar pinggang yang normal $<80 \mathrm{~cm}$ dengan nilai $75,8 \pm 10,8 \mathrm{~cm}$ dan $74,4 \pm 11,6 \mathrm{~cm}$ untuk kelompok Fe dan Fe+Vit C. Rata-rata tekanan darah kelompok Fe adalah 108,2/72,7 $\mathrm{mm} / \mathrm{Hg}$ dan 107,7/69,2 untuk kelompok Fe+Vit C. Sementara itu nilai tengah kadar $\mathrm{Hb}$ kedua kelompok tergolong rendah $(<12 \mathrm{~g} / \mathrm{dL})$ yaitu 10,7 g/dL pada kelompok Fe dan 11,1 g/dL pada kelompok Fe+Vit $\mathrm{C}$.

Tabel 1. Karakteristik Subjek

\begin{tabular}{lcc}
\hline \multicolumn{1}{c}{ Variabel } & $\begin{array}{c}\mathrm{Fe} \\
(\mathrm{n}=29)\end{array}$ & $\mathrm{Fe}+\mathrm{Vit} \mathrm{C}(\mathrm{n}=27)$ \\
\hline Berat badan $(\mathrm{kg})$ & $52,0 \pm 8,4$ & $53,4 \pm 57,1$ \\
Tinggi badan $(\mathrm{cm})$ & $154,2 \pm 4,3$ & $156,2 \pm 5,5$ \\
Indeks Massa Tubuh $\left(\mathrm{kg} / \mathrm{m}^{2}\right)$ & $21,8 \pm 3,3$ & $21,9 \pm 2,7$ \\
Lingkar lengan atas $(\mathrm{cm})$ & $24,5 \pm 2,8$ & $24,5 \pm 1,9$ \\
Lingkar pinggang $(\mathrm{cm})$ & $75,8 \pm 10,8$ & $74,4 \pm 11,6$ \\
Tekanan darah $(\mathrm{mm} / \mathrm{Hg})$ & & \\
$\quad$ Sistolik & $108,2 \pm 9,7$ & $107,7 \pm 11,7$ \\
$\quad$ Diastolik & $72,7 \pm 7,9$ & $69,2 \pm 7,9$ \\
$\mathrm{Hb}$ (g/dL) & 10,7 & 11,1 \\
\hline
\end{tabular}

*) Data menggunakan median

Tabel 2 menunjukkan bahwa sebagian besar subjek pada kelompok $\mathrm{Fe}$ dan $\mathrm{Fe}+\mathrm{Vit}$ C memiliki status gizi normal $(86,2 \%$ dan $88,9 \%)$. Sebagian besar subjek pada kelompok Fe $(58,6 \%)$ dan kelompok Fe+Vit C $(74,1 \%)$ juga memiliki LiLA $\geq 23,5 \mathrm{~cm}$. Lingkar pinggang 75,9 persen subjek pada kelompok $\mathrm{Fe}$ dan 59,3 persen kelompok $\mathrm{Fe}+\mathrm{Vit} \mathrm{C}$ berada dalam kategori normal $(<80 \mathrm{~cm})$. Sementara itu untuk variabel tekanan darah, tidak terdapat subjek yang memiliki tekanan darah tinggi.
Sebagian besar subjek termasuk normotensi atau tekanan darah normal. Namun demikian, pada kelompok $\mathrm{Fe}+\mathrm{Vit} \mathrm{C}$ terdapat 3,7 persen subjek yang termasuk hipotensi berdasarkan tekanan darah sistolik dan 11,1 persen termasuk hipotensi berdasarkan tekanan darah diastolik. Berdasarkan kadar $\mathrm{Hb}$, sebesar 58,6 persen subjek pada kelompok $\mathrm{Fe}$ memiliki status anemia ringan sementara pada kelompok Fe+Vit C sebanyak 55,6 persen subjek tergolong memiliki status anemia sedang. 
Tabel 2. Sebaran Karakteristik Subjek

\begin{tabular}{|c|c|c|c|c|}
\hline \multirow{2}{*}{ Variabel } & \multicolumn{2}{|c|}{$\mathrm{Fe}$} & \multicolumn{2}{|c|}{$\mathrm{Fe}+\mathrm{Vit} \mathrm{C}$} \\
\hline & $\mathrm{n}$ & $\%$ & $\mathrm{n}$ & $\%$ \\
\hline \multicolumn{5}{|l|}{ Status Gizi (IMT/U) } \\
\hline Normal & 25 & 86,2 & 24 & 88,9 \\
\hline Overweight & 3 & 10,3 & 2 & 7,4 \\
\hline Obesitas & 1 & 3,4 & 1 & 3,7 \\
\hline \multicolumn{5}{|l|}{ Lingkar lengan atas } \\
\hline$<23,5 \mathrm{~cm}$ & 12 & 41,4 & 7 & 25,9 \\
\hline$\geq 23,5 \mathrm{~cm}$ & 17 & 58,6 & 20 & 74,1 \\
\hline \multicolumn{5}{|l|}{ Lingkar pinggang } \\
\hline$<80 \mathrm{~cm}$ & 22 & 75,9 & 16 & 59,3 \\
\hline$\geq 80 \mathrm{~cm}$ & 7 & 24,1 & 11 & 40,7 \\
\hline \multicolumn{5}{|l|}{ Tekanan darah sistolik } \\
\hline Hipotensi $(<90$ mm/Hg) & 0 & 0,0 & 1 & 3,7 \\
\hline Normal (90-119 mm/Hg) & 26 & 89,7 & 22 & 81,5 \\
\hline Prehipertensi (120-139 mm/Hg) & 3 & 10,3 & 4 & 14,8 \\
\hline \multicolumn{5}{|l|}{ Tekanan darah diastolik } \\
\hline Hipotensi (<60 mm/Hg) & 0 & 0,0 & 3 & 11,1 \\
\hline Normal (60-79 mm/Hg) & 21 & 72,4 & 21 & 77,8 \\
\hline Prehipertensi $(80-89$ mm/Hg) & 8 & 27,6 & 3 & 11,1 \\
\hline \multicolumn{5}{|l|}{ Status anemia berdasarkan $\mathrm{Hb}$} \\
\hline Anemia ringan $(11-11,9 \mathrm{~g} / \mathrm{dL})$ & 17 & 58,6 & 12 & 44,4 \\
\hline Anemia sedang (8-10,9 g/dL) & 12 & 41,4 & 15 & 55,6 \\
\hline
\end{tabular}

Uji beda variabel tekanan darah dan kadar hemoglobin subjek dianalisis statistik secara inferensia (Tabel 3). Hasil uji beda kedua kelompok perlakuan menunjukan bahwa tidak terdapat perbedaan yang signifikan pada variabel tekanan darah sistolik, diastolik, dan kadar hemoglobin subjek baik sebelum maupun sesudah intervensi. Hal ini ditunjukkan oleh nilai $p^{a>0,05}$ sebagai hasil uji beda pada kedua kelompok perlakuan. Adapun hasil uji berpasangan menunjukkan bahwa tekanan darah sistolik sebelum dan sesudah perlakuan pada kedua kelompok tidak berbeda nyata $\left(p^{b}>0,05\right)$. Perubahan rata-rata tekanan darah sistolik dan diastolik pada kedua kelompok tidak berbeda nyata. Perbedaan yang signifikan ditunjukkan pada rata-rata kadar hemoglobin sebelum dan sesudah perlakuan baik pada kelompok $\mathrm{Fe}$ maupun $\mathrm{Fe}+\mathrm{Vit} \mathrm{C}$ dengan $p^{b}<0,05$. Pada kelompok Fe terjadi peningkatan kadar hemoglobin darah dari 10,7 g/dL sebelum intervensi menjadi 13,0 $\mathrm{g} / \mathrm{dL}$ sesudah intervensi. Kenaikan kadar hemoglobin juga terdapat pada kelompok intervensi $\mathrm{Fe}+\mathrm{Vit} \mathrm{C}$ dari $11,1 \mathrm{~g} / \mathrm{dL}$ menjadi $12,4 \mathrm{~g} / \mathrm{dL}$ setelah 90 hari intervensi dilakukan. Namun demikian, jika dilihat dari perubahan kadar hemoglobin antara kelompok $\mathrm{Fe}$ dan $\mathrm{Fe}+\mathrm{Vit} \mathrm{C}$ tidak terdapat perbedaan yang nyata pada kedua kelompok. 
Efektivitas Suplementasi Zat Besi ... (Pibriyanti K, Nurohmi S, Sari DD)

Tabel 3. Hasil Uji Beda Tekanan Darah dan Kadar Hemoglobin

\begin{tabular}{cccc}
\hline \multicolumn{1}{c}{ Variabel } & $\mathrm{Fe}$ & $\mathrm{Fe}+\mathrm{Vit} \mathrm{C}$ & $p^{a}$ \\
\hline Tekanan darah sistolik & & & \\
Sebelum & $108,2 \pm 9,7$ & $107,7 \pm 11,7$ & 0,842 \\
Sesudah & $109,0 \pm 8,2$ & $107,3 \pm 9,8$ & 0,492 \\
$\Delta$ & $0,76 \pm 12,9$ & $-0,33 \pm 15,6$ & 0,776 \\
$p^{b}$ & 0,755 & 0,912 & \\
Tekanan darah diastolik & & & \\
Sebelum & $72,7 \pm 7,9$ & $69,2 \pm 7,9$ & 0,103 \\
Sesudah & $72,9 \pm 6,6$ & $69,6 \pm 8,1$ & 0,102 \\
$\Delta$ & $0,21 \pm 10,8$ & $0,44 \pm 11,8$ & 0,938 \\
$p^{b}$ & 0,919 & 0,846 & \\
Kadar Hb & & & \\
Sebelum & 10,7 & 11,1 & 0,288 \\
Sesudah & 13,0 & 12,4 & 0,621 \\
$\Delta$ & 2,1 & 1,6 & 0,302 \\
$p^{b}$ & $0,000^{*}$ & $0,002^{*}$ & \\
\hline
\end{tabular}

a) uji beda antar dua kelompok perlakuan

$\left.{ }^{b}\right)$ uji beda antara sebelum dan sesudah perlakuan

$\Delta$ ) selisih rata-rata variabel sebelum dan sesudah perlakuan

$\left.{ }^{\dagger}\right)$ penyajian data menggunakan median dengan uji non parametris

*) signifikan pada taraf uji $\alpha<0,05$

Perubahan kadar hemoglobin setelah intervensi dilakukan pada kedua kelompok mengubah status anemia pada subjek. Tabel 4 menunjukkan sebaran subjek berdasarkan status anemia. Sebagian besar subjek baik kelompok $\mathrm{Fe}(75,9 \%)$ maupun $\mathrm{Fe}+\mathrm{Vit} \mathrm{C}$ $(66,7 \%)$ termasuk nonanemia dengan kadar hemoglobin $\geq 12 \mathrm{~g} / \mathrm{dL}$. Subjek dengan status anemia ringan mengalami penurunan menjadi 17,2 persen pada kelompok Fe dan 18,5 persen pada kelompok $\mathrm{Fe}+\mathrm{Vit} \mathrm{C}$. Adapun subjek dengan status anemia sedang hanya 6,9 persen dan 14,8 persen pada kelompok Fe dan Fe+Vit C.

Tabel 4. Status Anemia setelah Intervensi

\begin{tabular}{lcccccc}
\hline \multirow{2}{*}{ Status Anemia } & \multicolumn{2}{c}{$\mathrm{Fe}$} & & \multicolumn{2}{c}{$\mathrm{Fe}+\mathrm{Vit}$ C } \\
\cline { 2 - 3 } \cline { 5 - 7 } & $\mathrm{n}$ & $\%$ & & $\mathrm{n}$ & $\%$ \\
\hline Anemia ringan $(11-11,9 \mathrm{~g} / \mathrm{dL})$ & 5 & 17,2 & & 5 & 18,5 \\
Anemia sedang $(8-10,9 \mathrm{~g} / \mathrm{dL})$ & 2 & 6,9 & & 4 & 14,8 \\
Nonanemia $(\geq 12 \mathrm{~g} / \mathrm{dL})$ & 22 & 75,9 & & 18 & 66,7 \\
\hline
\end{tabular}


Tabel 5 menunjukkan bahwa asupan energi dan zat gizi subjek pada dua kelompok yang didapatkan dari konsumsi makanan selain suplemen yang diberikan tergolong dalam kategori defisit. Nilai tengah tingkat kecukupan energi kelompok Fe dan Fe+Vit C sebesar 59,9 persen dan 66,1 persen sedangkan untuk protein 61,5 persen dan 70,4 persen. Asupan vitamin A, vitamin $C$, vitamin $B 12$, dan asam folat kurang dari angka kecukupan gizi. Tingkat kecukupan vitamin subjek kurang dari 60 persen bahkan nilai tengah untuk tingkat kecukupan vitamin C hanya 16,3 persen untuk kelompok Fe dan
23,4 persen untuk kelompok Fe+Vit C. Terdapat perbedaan yang signifikan pada asupan vitamin B12 antara kedua kelompok. Asupan vitamin B12 pada kelompok Fe lebih tinggi dibandingkan pada kelompok Fe+Vit C. Asupan mineral kedua kelompok juga tergolong rendah dan tidak mencapai setengah dari kecukupannya kecuali tingkat kecukupan zink pada kelompok Fe+Vit C mencapai 51,8 persen. Tidak terdapat perbedaan yang nyata pada asupan mineral kedua kelompok subjek baik untuk kalsium, zat besi, maupun zink.

Tabel 5. Gambaran Asupan Zat Gizi Akhir Intervensi

\begin{tabular}{|c|c|c|c|}
\hline Zat gizi & $\mathrm{Fe}$ & Fe+Vit C & $p$ \\
\hline Energi† (kkal) & 1258 & 1387 & \multirow{2}{*}{0,456} \\
\hline Tingkat kecukupan (\%) & 59,9 & 66,1 & \\
\hline $\operatorname{Protein}^{\dagger}(\mathrm{g})$ & 39,9 & 45,7 & \multirow{2}{*}{0,254} \\
\hline Tingkat kecukupan (\%) & 61,5 & 70,4 & \\
\hline Vitamin $\mathrm{A}^{\dagger}(\mathrm{RE})$ & 335,3 & 237,1 & \multirow{2}{*}{0,923} \\
\hline Tingkat kecukupan (\%) & 55,9 & 39,5 & \\
\hline Vitamin $\mathrm{C}^{\dagger}(\mathrm{mg})$ & 12,3 & 17,6 & \multirow{2}{*}{0,674} \\
\hline Tingkat kecukupan (\%) & 16,3 & 23,4 & \\
\hline Vitamin B12 (mcg) & 1,3 & 0,9 & \multirow{2}{*}{$0,043^{*}$} \\
\hline Tingkat kecukupan (\%) & 32,8 & 23,7 & \\
\hline Asam Folat (mcg) & 147,5 & 157,0 & \multirow{2}{*}{0,974} \\
\hline Tingkat kecukupan (\%) & 36,9 & 39,3 & \\
\hline Kalsium (mg) & 531,0 & 373,4 & \multirow{2}{*}{0,497} \\
\hline Tingkat kecukupan (\%) & 44,3 & 31,2 & \\
\hline Zat Besi' (mg) & 7,2 & 5,7 & \multirow{2}{*}{0,314} \\
\hline Tingkat kecukupan (\%) & 48,3 & 38,2 & \\
\hline Zink $^{\dagger}(\mathrm{mg})$ & 4,0 & 4,6 & \multirow{2}{*}{0,05} \\
\hline Tingkat kecukupan (\%) & 43,9 & 51,8 & \\
\hline
\end{tabular}

$\left.{ }^{\dagger}\right)$ penyajian data menggunakan median dengan uji non parametris

$\left.{ }^{*}\right)$ signifikan pada taraf uji $\alpha<0,05$

\section{PEMBAHASAN}

Sampel dari kedua kelompok adalah santri putri usia remaja yang memiliki status gizi normal berdasarkan IMT/U. Meskipun terdapat beberapa santri yang overweight dan obesitas, namun demikian tidak terdapat santri yang memiliki status gizi underweight. Data menunjukkan status gizi remaja di Indonesia 
dari tahun 1999-2015 telah banyak mengalami pergeseran. Angka underweight mulai mengalami penurunan pada masa ini, tetapi angka overweight dan obesitas meningkat. ${ }^{19}$ Masa remaja merupakan masa pertumbuhan dan perkembangan pesat yang terjadi dalam siklus kehidupan. Fase ini merupakan fase kritis sehingga zat gizi dan pola hidup perlu diperhatikan untuk menunjang status kesehatan pada fase ini dan fase selanjutnya. Pemilihan makanan dan aktivitas fisik merupakan faktor yang sangat berpengaruh terhadap status gizi pada masa remaja ini. ${ }^{20} \mathrm{Aktivitas}$ yang dilakukan santri di pondok pesantren pada umumnya terjadwal dan padat. Mustika dalam penelitiannya menyebutkan bahwa tingkat aktivitas fisik pada santri tergolong dalam kategori sedang dan sebagian besar santri (97\%) memiliki status gizi yang normal. ${ }^{21}$

Berdasarkan LiLA, sampel kedua kelompok menunjukkan bahwa sebagian besar subjek tidak berisiko KEK (LiLA $\geq 23,5 \mathrm{~cm}$ ). Terdapat beberapa subjek yang memilliki LiLA <23,5 $\mathrm{cm}$ namun persentasenya kecil. Penilaian antropometri dengan pendekatan LiLA dapat menjadi alternatif untuk menilai status gizi. LiLA dapat digunakan sebagai indikator risiko kurang energi kronis (KEK) pada wanita usia subur. ${ }^{22}$ Penelitian ini menunjukkan bahwa LiLA sebagian besar subjek tidak berisiko KEK karena memiliki LiLA $\geq 23,5 \mathrm{~cm}$ meskipun terdapat beberapa subjek yang memilliki LiLA $<23,5 \mathrm{~cm}$. Global Alliance for Improved Nutrition melaporkan bahwa rata-rata LiLA wanita yang tidak hamil pada usia 15-17 tahun $<23,5 \mathrm{~cm}^{23}$ Namun demikian, hasil Riset Kesehatan Dasar tahun 2018 melaporkan bahwa remaja putri pada usia 15-18 tahun memiliki LiLA pada kisaran 24,3-25,0 cm. ${ }^{3}$

Rata-rata lingkar pinggang subjek kedua kelompok termasuk normal, yaitu tidak lebih dari $80 \mathrm{~cm}$. Namun, nilai rata-rata pada penelitian ini lebih tinggi daripada nilai pada penelitian sebelumnya dengan rata-rata $69,08 \mathrm{~cm} .{ }^{24}$ Sampel yang memiliki lingkar pinggang tinggi $\geq 80 \mathrm{~cm}$, ditemukan hanya sebesar 24,1 persen pada kelompok Fe dan 40,7 persen pada kelompok Fe+Vit C. Sedangkan berdasarkan IMT/U, sampel dengan IMT/U yang dikategorikan tinggi yaitu overweight dan obesitas ditemukan pada kelompok Fe+Vit C hanya sebesar 7,4 persen dan 3,7 persen dan pada kelompok $\mathrm{Fe}$ sebanyak 10,3 persen dan 3,4 persen. Lingkar pinggang dapat mewakili indikator obesitas sentral yang dapat memprediksi keberadaan lemak abdominal (distribusi lemak) yang erat kaitannya dengan perkembangan penyakit kardiovaskuler, sebaliknya IMT digunakan sebagai indikator adiposa secara keseluruhan yang menggambarkan status gizi secara umum. ${ }^{25}$ Remaja dengan status gizi lebih dan obesitas memiliki risiko tinggi mengalami tekanan darah tinggi. ${ }^{26}$ Beberapa penyakit seperti penyakit jantung dan kerusakan organ lain dapat dipicu karena tekanan darah tinggi.

Sebagian besar subjek pada penelitian ini memiliki tekanan darah normal baik sistolik maupun diastolik. Pada penelitian lain dengan subjek remaja juga didapatkan mayoritas memiliki tekanan darah normal. ${ }^{26,27}$ Tekanan darah sebelum dan sesudah intervensi dalam penelitian ini, tidak berubah secara signifikan. Rata-rata tekanan darah sistolik dan diastolik masih dalam kategori normal. Walaupun ditemukan tekanan darah yang dikategorikan prehipertensi namun persentasenya rendah. Di Indonesia, prevalensi tekanan darah tinggi remaja yaitu 8,4 persen pada tahun 2013. ${ }^{26}$ Risiko kejadian hipertensi pada remaja dapat meningkat karena faktor kualitas tidur, IMT/U, dan riwayat hipertensi keluarga. ${ }^{28}$

Berbeda dengan variabel tekanan darah, kadar hemoglobin subjek mengalami kenaikan yang signifikan pada dua kelompok intervensi. Intervensi ini berpengaruh pada perbaikan status anemia dikarenakan kadar hemoglobin 
subjek $\geq 12 \mathrm{~g} / \mathrm{dL}$. Dalam sebuah studi cross sectional menyebutkan bahwa kadar hemoglobin dipengaruhi oleh asupan zat besi, vitamin $\mathrm{C}$, dan vitamin B12 pada remaja. ${ }^{34}$ Dalam tubuh manusia, zat besi terikat dengan protein sebagai senyawa heme (hemoglobin atau mioglobin), enzim heme, atau senyawa nonheme seperti flavin-iron enzyme, transferin atau ferritin. Dalam hal ini zat besi akan berperan dalam transpor oksigen, komponen beberapa enzim dalam proses transpor elektron, dan terlibat dalam reaksi redoks. Hampir dua per tiga zat besi dalam tubuh ditemukan pada hemoglobin yang bersirkulasi bersama eritrosit. ${ }^{30}$ Oleh karena itu, asupan zat besi dari diet sangat diperlukan agar hemoglobin dapat berperan sebagaimana fungsinya.

Penyerapan zat besi dalam tubuh dapat dibantu oleh vitamin C. ${ }^{9}$ Sebagaimana zat besi dominan yang terdapat dalam makanan berbentuk $\mathrm{Fe}^{3+}$ namun memiliki bioavailabilitas yang rendah, vitamin $\mathrm{C}$ atau asam askorbat dapat memfasilitasi $\mathrm{Fe}^{3+}$ untuk mengurangi jumlah ionnya menjadi $\mathrm{Fe}^{2+}$. Bentuk $\mathrm{Fe}^{2+}$ diketahui memiliki bioavailabilitas yang lebih baik dibandingkan $\mathrm{Fe}^{3+}$. Oleh karena itu, penambahan vitamin $\mathrm{C}$ diharapkan mampu memberikan efek yang lebih baik pada suplementasi zat besi. ${ }^{31}$

Penelitian ini menunjukkan bahwa selisih rata-rata kadar hemoglobin antara kelompok $\mathrm{Fe}$ dan $\mathrm{Fe}+\mathrm{Vit} \mathrm{C}$ tidak berbeda nyata. Hal ini menunjukkan bahwa kedua perlakuan memiliki efektivitas yang sama dalam meningkatkan kadar hemoglobin dalam darah. Penelitian yang sebelumnya dilakukan pada wanita usia subur 15-45 tahun dengan perlakuan yang sama menunjukkan bahwa pemberian suplemen zat besi disertai vitamin $\mathrm{C}$ memberikan pengaruh yang lebih baik dalam meningkatkan kadar hemoglobin dibandingkan dengan pemberian suplemen zat besi saja. ${ }^{32}$ Perbedaan hasil ini dapat disebabkan oleh dosis suplemen yang diberikan berbeda. Selain itu penyerapan zat besi selain dipengaruhi oleh vitamin $\mathrm{C}$ juga dapat terhambat dengan adanya zat gizi lain seperti zink, fitat, atau tanin..$^{33,34,35}$ Namun dalam riset ini, tingkat kepatuhan atau monitoring pemberian tablet Fe dan vitamin $\mathrm{C}$ belum dilakukan sehingga menjadi satu kelemahan dalam riset.

Berdasarkan Tabel 5, perhitungan asupan vitamin C subjek yang diperoleh dari diet saja tanpa tambahan suplemen menunjukkan nilai yang sangat rendah. Sementara itu, tubuh memerlukan vitamin $\mathrm{C}$ bukan hanya untuk membantu absorpsi besi melainkan juga berfungsi untuk membantu pembentukan formasi tulang, membantu perkembangan jaringan, membantu proses aktivasi asam amino, dan beberapa fungsi fisiologis lain. ${ }^{36}$ Penambahan vitamin C secara oral dalam bentuk tablet yang diberikan pada kelompok $\mathrm{Fe}+\mathrm{Vit} \mathrm{C}$ ternyata tidak memiliki dampak yang berarti untuk meningkatkan efektivitas suplementasi besi. Hasil penelitian yang sama juga dijelaskan oleh Li et al. yang menyatakan bahwa peningkatan hemoglobin pada kelompok subjek suplementasi besi ekuivalen dengan kelompok subjek suplementasi besi dan vitamin C. ${ }^{37}$ Pemberian vitamin $\mathrm{C}$ oral bersamaan dengan Fe yang menambah jumlah asupan, diduga akan digunakan untuk melakukan fungsi metabolik lain yang lebih diprioritaskan berdasarkan permintaan tubuh terhadap vitamin $\mathrm{C}$ tersebut.

Berdasarkan asupan energi, protein, vitamin, dan mineral yang didapatkan dari data diet pada akhir penelitian, tidak terdapat perbedaan yang signifikan antara kedua kelompok. Asupan protein yang cukup pada dasarnya diperlukan oleh tubuh dalam metabolisme zat gizi dalam hal ini zat besi dan zat gizi lain yang berperan dalam pembentukan sel darah merah seperti asam folat dan vitamin B12. Salah satu manfaat protein dalam tubuh adalah sebagai transporter yang mengangkut atau mengikat zat gizi untuk proses metabolisme. ${ }^{38}$ Namun asupan protein subjek pada kedua kelompok perlakuan cenderung 
rendah. Sama halnya dengan protein, asupan beberapa vitamin dan mineral subjek belum memenuhi tingkat kecukupan zat gizi. Namun demikian, asupan vitamin B12 menunjukkan hasil yang berbeda nyata dengan nilai pada kelompok Fe lebih tinggi dibandingkan kelompok Fe+Vit C meskipun tingkat kecukupan keduanya tergolong rendah. Seperti halnya zat besi dan asam folat, vitamin B12 merupakan salah satu zat gizi yang berpengaruh terhadap anemia. ${ }^{39}$ Asupan vitamin B12 yang lebih tinggi pada kelompok Fe diduga menjadikan suplementasi Fe yang diberikan memiliki efektivitas yang sama dengan kelompok Fe+Vit C. Penelitian yang dilakukan oleh Siallagan et al. menyatakan bahwa kadar hemoglobin pada subjek memiliki keterkaitan dengan asupan vitamin B12. ${ }^{29}$ Defisiensi vitamin B12 yang juga diketahui sebagai kobalamin dapat mengakibatkan kegagalan fungsi tulang belakang dan penyakit demielinasi karena ketidaknormalan dalam proses pembentukan sel darah merah dan pembentukan mielin pada sistem saraf pusat. Kelainan yang paling umum terjadi ketika tubuh mengalami defisiensi vitamin B12 adalah pernicious anemia. ${ }^{40}$

\section{KESIMPULAN}

Median kadar hemoglobin sebelum intervensi pada kelompok Fe adalah 10,7 g/ $\mathrm{dL}$ sedangkan pada kelompok $\mathrm{Fe}+\mathrm{Vit} \mathrm{C}$ adalah $11,1 \mathrm{~g} / \mathrm{dL}$. Median kadar hemoglobin mengalami peningkatan secara signifikan pada kelompok Fe dan Fe+Vit C menjadi 13,0 g/dL dan 12,4 $\mathrm{g} / \mathrm{dL}$ setelah intervensi dilakukan. Sebagian besar subjek pada kedua kelompok memiliki status nonanemia setelah intervensi dilakukan. Namun demikian, tidak terdapat perbedaan yang signifikan pada kadar hemoglobin setelah intervensi antara kedua kelompok perlakuan. Asupan vitamin $\mathrm{C}$ yang ditambahkan pada kelompok suplementasi Fe+Vit C tidak memberikan dampak yang signifikan terhadap peningkatan hemoglobin. Pada kelompok Fe, asupan vitamin B12 dalam diet selama intervensi lebih tinggi dibandingkan dengan kelompok $\mathrm{Fe}+\mathrm{Vit} \mathrm{C}$ meskipun tingkat kecukupan keduanya tergolong rendah.

\section{SARAN}

Penelitian ini menggunakan SQ FFQ dalam menentukan asupan energi dan zat gizi di akhir intervensi untuk melihat gambaran asupan energi dan zat gizi selama tiga bulan intervensi. Penelitian lanjutan perlu dilakukan menggunakan desain kuasi eksperimental dengan mengukur asupan zat gizi di awal, selama, dan akhir perlakuan serta melakukan pengumpulan dan analisis data yang berkaitan dengan zat penghambat penyerapan vitamin $C$. Selain itu, analisis biokimia feritin dan transferin saturation untuk melihat kadar dan cadangan zat besi dalam tubuh.

\section{UCAPAN TERIMA KASIH}

Penelitian ini terlaksana atas dukungan dari beberapa pihak. Oleh karena itu, penulis mengucapkan terima kasih kepada Kementerian Pendidikan dan Kebudayaan, Direktorat Riset dan Pendidikan Tinggi yang telah memberikan bantuan dana pada proposal riset yang berjudul Model Perbaikan Status Gizi Remaja dalam rangka Upaya Menurunkan Angka Anemia pada Santri. Ucapan terima kasih juga penulis sampaikan kepada Pondok Modern Darussalam Gontor Kampus Putri 1 Mantingan, Ngawi yang telah bersedia bekerja sama dalam penelitian ini.

\section{DAFTAR PUSTAKA}

1. Finkelstein JL, Herman HS, Guetterman HM, Peña-Rosas JP, Mehta S. Daily Iron Supplementation for Prevention or Treatment of Iron Deficiency Anaemia in Infants, Children, and Adolescents. Cochrane Database Syst Rev. 2018;2018(12):1-21. 
2. World Health Organization. The Global Strategy for Women's, Children's, and Adolescents' Health (2016-2030). Geneva: World Health Organization; 2015.

3. Kementerian Kesehatan RI. Laporan Nasional Hasil Riset Kesehatan Dasar (Riskesdas) Indonesia tahun 2018. Jakarta: Kementerian Kesehatan RI; 2019.

4. Widjaja IR, Widjaja FF, Santoso LA, Wonggokusuma E, Oktaviati O. Anemia Among Children and Adolescents in A Rural Area. Paediatr Indones. 2014;54(2):88-93.

5. Kementerian Kesehatan RI. Laporan Akuntabilitas Kerja tahun 2015. Jakarta: Direktorat Bina Gizi Ditjen Bina Gizi dan KIA; 2015.

6. Permatasari T, Briawan D, Madanijah S. Efektivitas Program Suplementasi Zat Besi pada Remaja Putri di Kota Bogor. Media Kesehatan Masyarakat Indonesia. 2018;14(1):1-8.

7. World Health Organization. Haemoglobin Concentrations for The Diagnosis of Anaemia and Assessment of Severity. Geneva: World Health Organization; 2011.

8. Lane DJR, Richardson DR. The Active Role of Vitamin C in Mammalian Iron Metabolism: Much More than Just Enhanced Iron Absorption. Free Radic Biol Med. 2014;75:69-83.

9. Kalinowski DS, Stefani C, Toyokuni S, Ganz T, Anderson GJ, Subramaniam NV, et al. Redox Cycling Metals: Pedaling Their Roles in Metabolism and Their Use in The Development of Novel Therapeutics. Biochim Biophys Acta - Mol Cell Res. 2016;1863(4):727-48.

10. Krisnanda R. Vitamin C Membantu dalam Absorpsi Zat Besi pada Anemia Defisiensi Besi. J Penelit Perawat Prof. 2019;1:89-94.
11. Sastroasmoro S, Ismael S. Dasar-Dasar Metodologi Penelitian Klinis. Jakarta: CV. Sagung Seto; 2008.

12. Mehta R, PlattAC, Sun X, Desai M, Clements D, Turner EL. Efficacy of Iron-Supplement Bars to Reduce Anemia in Urban Indian. Am J Clin Nutr. 2017;105(3):746-57.

13. World Health Organization. Guideline Daily Iron Supplementation in Infants and Children. Geneva: World Health Organization; 2016.

14. Harjatmo TP, Par'i HM, Wiyono S. Penilaian Status Gizi. Jakarta: Pusat Pendidikan Sumber Daya Manusia Kesehatan, Kementerian Kesehatan RI; 2017.

15. Kementerian Kesehatan RI. Peraturan Menteri Kesehatan Republik Indonesia Nomor 2 Tahun 2020 Tentang Standar Antropometri Anak. Jakarta: Kementerian Kesehatan RI; 2020.

16. Anuradha R, Hemachandran S, Dutta R. The Waist Circumference Measurement: A Simple Method for Assessing The Abdominal Obesity. J Clin Diagnostic Res. 2012;6(9):1510-3.

17. Perhimpunan Dokter Spesialis Kardiovaskuler Indonesia. Panduan Tata Laksana Dislipidemia. Jakarta: Perhimpunan Dokter Spesialis Kardiovaskuler Indonesia; 2017.

18. Kementerian Kesehatan RI. Peraturan Menteri Kesehatan Republik Indonesia Nomor 28 Tahun 2019 tentang Angka Kecukupan Gizi yang Dianjurkan untuk Masyarakat Indonesia. Jakarta: Kementerian Kesehatan RI; 2019.

19. World Health Organization. Global Nutrition Report: Nutrition Country Profile Indonesia. Geneva: World Health Organization; 2018. 
20. Maehara M, Rah JH, Roshita A, Suryantan J, Rachmadewi A, Izwardy D. Patterns and Risk Factors of Double Burden of Malnutrition among Adolescent Girls and Boys in Indonesia. PLoS One. 2019;14(8):15-8.

21. Mustika MA. Tingkat Aktivitas Fisik, Tingkat Konsumsi Zat Gizi dan Status Gizi Siswa di Pondok Pesantren Al Falak Kota Bogor. Skripsi. Bogor: Fakultas Ekologi Manusia Institut Pertanian Bogor, 2012.

22. Putri DD, Ulvie YN, Bening S. Status Gizi pada Remaja Putri di MAN 1 Semarang. Semarang: Universitas Muhamadiyah Semarang, 2018. Diunduh dari: http:// repository.unimus.ac.id/2444/43/ MANUSCRSPT.pdf, tanggal 18 September 2020.

23. Global Alliance for Improved Nutrition. Adolescent and Maternal Nutrition in Indonesia. Geneva: Global Alliance for Improved Nutrition; 2014.

24. Mulyasari I, Pontang GS. Waist Circumference and Waist-to-Height Ratio as Indicators for Excess Adiposity in Adolescents. J Gizi dan Pangan. 2018;13(3):131-6.

25. Ji CY, Ytsung R, Ma GS, Ma J, He ZH, Chen TJ. Waist Circumference Distribution of Chinese School-Age Children and Adolescents. Biomed Environ Sci. 2010;23(1):12-20.

26. Merdianti R, Hidayati L, Asmoro CP. Hubungan Status Nutrisi dan Gaya Hidup terhadap Tekanan Darah pada Remaja di Kelurahan Lidah Kulon Kota Surabaya. Journal of Ners and Midwifery. 2019;6(2):218-26.

27. Tooy R, Manampiring A, Fatimawali. Gambaran Tekanan Darah Pada Remaja Obes di Kabupaten Minahasa. Jurnal e-Biomedik. 2013;1(2):951-55.
28. Shaumi NRF, Achmad EK. Kajian Literatur: Faktor Risiko Hipertensi pada Remaja di Indonesia. Media Penelit dan Pengemb Kesehat. 2019;29(2):115-22.

29. Siallagan D, Swamilaksita PD, Angkasa D. Pengaruh Asupan Fe, Vitamin A, Vitamin B12, dan Vitamin C terhadap Kadar Hemoglobin pada Remaja Vegan. J Gizi Klin Indones. 2016;13(2):67-74.

30. Abbaspour N, Hurrell R, Kelishadi R. Review on Iron and Its Importance for Human Health. J Res Med Sci. 2014;19(2):164-74.

31. Teucher B, Olivares M, Cori H. Enhancers of Iron Absorption: Ascorbic Acid and Other Organic Acids. Int J Vitam Nutr Res. 2004;74(6):403-19.

32. Utama TA, Listiana $N$, Susanti $D$. Perbandingan Zat Besi dengan dan Tanpa Vitamin C terhadap Kadar Hemoglobin Wanita Usia Subur. J Kesehat Masy Nas. 2013;7(8):344-8.

33. Khoshfetrat MR, Mortazavi S, Neyestani T, Mahmoodi MR, Shoae NZ, Nasrabadi FM. Iron and Vitamin C CoSupplementation Increased Serum Vitamin C Without Adverse Effect on Zinc Level in Iron Deficient Female Youth. International Journal of Preventive Medicine. 2014;5(8):1037-44.

34. Al Hasan SM, Hassan M, Saha S, Islam M, Billah M, Islam S. Dietary Phytate Intake Inhibits The Bioavailability of Iron and Calcium in The Diets of Pregnant Women in Rural Bangladesh: A Cross-Sectional Study. BMC Nutr. 2016;2(24):1-10.

35. Machmud PB, Hatma RD, Syafiq A. Tea Consumption and Iron-Deficiency Anemia among Pregnant Woman in Bogor District, Indonesia. MGMI. 2019;10(2):91-100. 
36. Chambial S, Dwivedi S, Shukla KK, John PJ, Sharma P. Vitamin C in Disease Prevention and Cure: An Overview. Indian J Clin Biochem. 2013;28(4):314-28.

37. Li N, Zhao G, Wu W, Zhang M, Liu W, Chen $Q$, et al. The Efficacy and Safety of Vitamin $\mathrm{C}$ for Iron Supplementation in Adult Patients with Iron Deficiency Anemia: A Randomized Clinical Trial. JAMA Netw Open. 2020;3(11):e2023644.

38. De Silva N, Davis B. Iron, B12 and Folate. Medicine. 2013;41(4):204-7.
39. Song SM, Bae KW, Yoon HS, Im HJ, Seo JJ. A Case of Anemia Caused by Combined Vitamin B12 and Iron Deficiency Manifesting as Short Stature and Delayed Puberty. Korean J Pediatr. 2010;53(5):661-5.

40. Prueksaritanond $S$, Barbaryan $A$, Mirrakhimov AE, Liana P, Ali AM, Gilman AD. A Puzzle of Hemolytic Anemia, Iron and Vitamin B12 Deficiencies in a 52-YearOld Male. Case Report in Hematology. 2013;2013:1-5. 